\title{
GEODIVERSITY AND GEOHERITAGE ASSESSMENT IN HULU LANGAT DISTRICT, SELANGOR, MALAYSIA
}

\author{
Muzaffar YUSRY \\ Institute for Environment and Development (LESTARI), University Kebangsaan \\ Malaysia, 4360o Bangi, Selangor, e-mail: muzaffaryusry@siswa.ukm.edu.my
}

\section{Norbert SIMON}

Geology Programme, School of Environmental Sciences and Natural Resources, Faculty of Science and Technology, University Kebangsaan Malaysia, 43600 Bangi, Selangor, e-mail: norbsn@ukm.edu.my

Tanot UNJAH*

Institute for Environment and Development (LESTARI), University Kebangsaan Malaysia, 43600 Bangi, Selangor, e-mail: tanot-u@ukm.edu.my

Citation: Yusry, M., Simon, N., \& Unjah, T. (2018). GEODIVERSITY AND GEOHERITAGE ASSESSMENT IN HULU LANGAT DISTRICT, SELANGOR, MALAYSIA. GeoJournal of Tourism and Geosites, 23(3), 861-872. https://doi.org/10.30892/gtg.23320-334

\begin{abstract}
Assessment of valuable geological resources is critical in ensuring sustainable utilization of resources at geological sites for education, tourism, recreational and conservation purposes. This research aims to develop a comprehensive method of assessing heritage resources of geological sites based on four values, scientific, aesthetic, recreational and culture in Hulu Langat. The assessment method employed in this research utilised conservation geology approach in order to to establish criteria for the four values that incorperating knowledge of other discipline, namely ecology, history and economic. Specific weightage are given for each criterion in the four values, with an empahis on scientific significance. Based on the total score, each geological sites are classified into geofeature, geosite or geotop. Additional data consisting of basic info and environmental functions, support the classification of assessed geological sites. In Hulu Langat, it was found that most of the geological sites are geofeatures. However additional data obtained shows that they also already function as a recreational area or water catchment and located within forest reserve. Therefore, the geofeatures are proposed as sites for geotourism and as conservation area. The study also recognised the assessment method developed using gelogical landscape approach in this study be able to captured the intangible and tangible significant of the geological sites.
\end{abstract}

Keywords: assessment, geological site, geotourism, geodiversity, geoheritage

\footnotetext{
* Corresponding author
} 


\section{INTRODUCTION}

Heritage assessment of a geological site is a classification process of geological sources and natural landscape according to the importance of the heritage level. This assessment process has been used for more than a decade in Malaysia within the context of conservation geology to identify the intrinsic value of geological features and the heritage value of the site (Komoo, 2000; Komoo, 2003; Komoo \& Md Desa, 1997; Sarman et al., 1999; Unjah, 2003). To produce an effective heritage assessment of a geological site, several value criteria must be considered, namely, scientific, aesthetic, recreational and cultural value criteria. The geological landscape concept (Komoo \& Othman, 2001) and the scientific assessment criteria (Reynard et al., 2007; Rovere et al., 2010) are used as tools to assess the scientific aspect of a heritage site. With regard to the heritage assessment of a site based on the aesthetic, recreational and cultural aspects, the criteria are collated from a combination of various disciplines (Armenski et al., 2012; Brilha, 2016; Dwyer \& Kim, 2003; Goffi, 2013; Kane, 1976; Leopold, 1969; Pereira et al., 2007; Vengesayi, 2003). Incorporating various concepts into conservation geology when conducting a heritage assessment of a geological site is necessary to achieve the sustainable use of natural resources in Malaysia.

The heritage assessment process must be conducted systematically to provide basic understanding and awareness of the importance of geological sites to the public around Hulu Langat District. The pivotal role of these sites in sustaining the natural processes of a geological site was the main issue that was accorded due attention. This idea followed the acknowledgment that a geological site is a crucial and concrete evidence of the formation and evolution of the earth's surface through the processes of rock formation, fossils and various landforms (Doyle et al., 1994). The landscape and geological features ascertained to have a high value were considered important assets for conserving permanent forest reserves (PFRs) for ecotourism, recreation and education (Leman et al., 2007). Furthermore, a geological site must be well preserved to ensure that the scientific value from the geological and geomorphological evolution process and the added advantage from the aesthetic, recreational and cultural values could be appreciated by not only the current but also the future generation.

The forest reserve area around Hulu Langat is a biodiversity habitat which mainly functions as a water catchment area supplying clean water to the residents around Klang Valley. This forest reserve can also be categorised as a recreational forest area which supports the local and national tourism industry, allocates a provision for setting up a natural recreational site, expands public amenities and increases public awareness of the significance of protecting nature (Hussein et al., 2013; Leman et al., 2007). The population growth and the rapid development of land use around Klang Valley resulted in increased demand on Hulu Langat's tourism sector. This progress has had a positive effect on the economy, especially on the tourism industry, but it had a negative effect on nature itself. As such, heritage assessment is needed to balance the use of the geological site in Hulu Langat between research, recreational tourism and conservation purposes. Beside, it is also important to address the relationship between geotourism with biodiversity and local people which seem to be lack among the existing research (Hakim \& Soemarno, 2017). This research paper intends to examine the effectiveness of the heritage assessment method by using the conservation geology approach, which is a combination of the geological landscape concept and the concepts of various other disciplines (namely, biology, history and economy). The approach allowed the heritage assessment method to be employed in scientific and non-scientific aspects of research to determine the type of geological site which would eventually be used either for geotourism or conservation. To date, researchers remain unaware of the significance of a 
large part of the geological site around the Hulu Langat District owing to the absence of a specific assessment of the results from the geological heritage evaluation conducted. The locality and heritage value of most geological sites have been identified (Zabidi et al., 2001). This effort protected not only the geological site but also the surrounding physical landscape and the people affected by unscrupulous and inadequate development.

\section{RESEARCH LOCATION}

Hulu Langat District (Figure 1) is situated southeast of the state of Selangor between Kuala Lumpur and Negeri Sembilan. Its coordinates are longitude 3.294292 ${ }^{\circ}$ and latitude $101.9012^{\circ}$. The area is approximately 82,620 hectares, making it the fifth largest district in the state of Selangor. Hulu Langat's administrative borders encompass two local authorities, namely, the Ampang Jaya Municipal Council and the Kajang Municipal Council. With regard to the terrain of this locality, the geographical nature of the area has evolved. The landscape has undergone a crucial tran sformation; it was a lowland area initially before the formation of hills, which formed mountains over time. Igneous (volcanic and plutonic) and metamorphic rocks (Hawthornden Schist, Jelebu Schist, Kenny Hill Formation) are the main geological units that shape the landscape of the earth in Hulu Langat (Norhayati \& Juhari, 2000). A total of 44.87 percent or 35,343.14 hectares of the area are composed of dipterocarp forest. A total of 31,109.84 hectares of the forest have been declared a Permanat Forest Reserve (PFR). The PFR consists of Sungai Lalang (17,027.77 hectares), Hulu Langat (13,843.52 hectares), Jerloh (203.62 hectares) and Batu Putih Selatan (34.93 hectars).

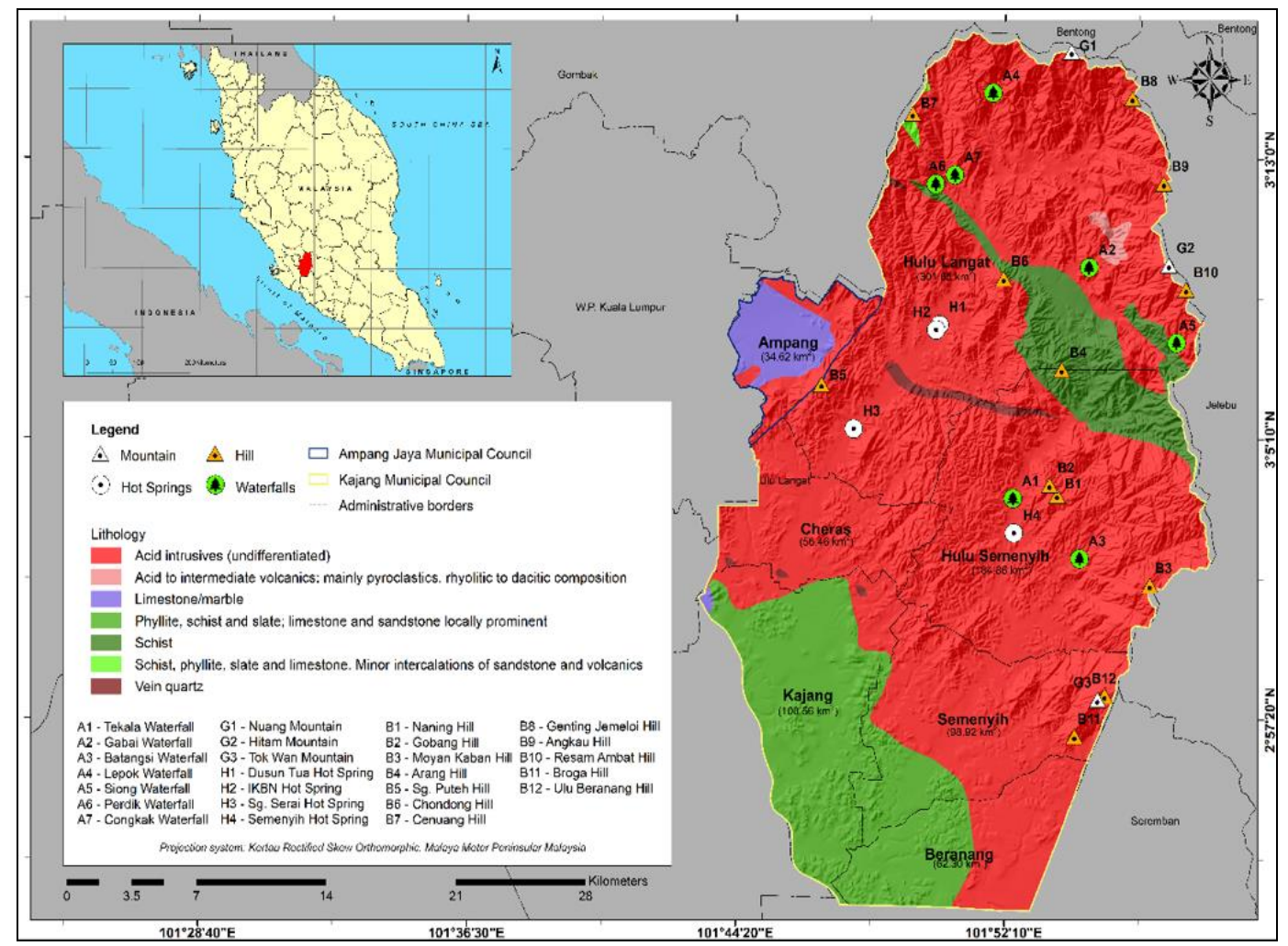

Figure 1. Map showing the location of an identified geological site locality in Hulu Langat District 


\section{ASSESSMENT METHOD}

\section{Current heritage assessment of a geological site}

The current assessment process within the conservation geology context involved the classification of the geological heritage sources and the major landscape areas. This classification process was conducted according to the significance level of a site considering unique geological features and vital changes to the earth's surface. The method of assessment of geological heritage sites usually focuses on geological criteria detailing the importance of the use of scientific evaluation methods for conservation and management. The reason behind this emphasis was that the heritage assessment method was strongly influenced by the geodiversity aspect during the classification process. The various methods applied in the heritage assessment of a geological site were developed by researchers at the local and international levels (Komoo et al., 2001; Reynard et al., 2007; Sharples, 1993; Sharples, 2002). This assessment approach centred on the scientific aspect of the geological sources rather than the non-scientific factor. The geological heritage resources in Malaysia are divided into 6 geodiversity, namely, rock, mineral, fossil, primary structure, secondary structure and landform diversity. The framework for the heritage assessment of a geological site incorporated scientific, aesthetic, cultural and recreational value components (Komoo, 2000). The assessment method employed included qualitative and quantitative data obtained through field observation, analysis and interpretation of the various processes and critical geological and geomorphological features and phenomena of a certain site. Nevertheless, the focal point of the current assessment method was qualitative descriptive research, which chronicled geological and geomorphological processes and phenomena. Furthermore, an absence of a scoring system when interpreting the heritage value level of each geological site was noted.

\section{Assessment based on the conservation geology approach}

The review of the heritage assessment aspect of a geological site based on the conservation geology approach was conducted using both indirect and direct surveys. Indirect survey involved mapping the earth's surface (such as topography, aerial photographs, satellite images and geological maps) to identify the locality of a geological site. The mapping technique has its advantages because it allows a greater view of an area compared with a field survey. This technique assisted in obtaining a preliminary description of the earth's surface and the lithology of the area being researched prior to conducting a direct survey. The mapping of the geological heritage locality completed by a Zabidi et al. (2001) aided the process of distinguishing the geological site to be valued. A total of 26 geological sites were identified around Hulu Langat District and categorised according to landform diversity: waterfalls, hot springs, hills and mountains that have the potential to be transformed into a site for geotourism or for conservation.

Table 1. General information on geological sites (Data source: Komoo et al., 2004)

\begin{tabular}{|c|c|c|}
\hline \multicolumn{3}{|c|}{ Part 1: General Information on Geological site } \\
\hline Гур & Name of Geological site & Diversity code \\
\hline $\begin{array}{l}\text { of geological site } \\
\text { rfall, hot springs, }\end{array}$ & $\begin{array}{l}\text { Name of the geological site that } \\
\text { has been identified }\end{array}$ & $\begin{array}{l}\text { Written as an acronym and in } \\
\text { capital letters (example: BT- } \\
\text { Batuan) }\end{array}$ \\
\hline ta & & \\
\hline $\begin{array}{l}\text { Refers to the state where the } \\
\text { geological site is found } \\
\text { (example: } 10-\text { Selangor). }\end{array}$ & $\begin{array}{l}\text { Write down the name of district } \\
\text { and village where the geological } \\
\text { site is found }\end{array}$ & $\begin{array}{l}\text { Latitude and longitude. } \\
\text { projection system on a natio } \\
\text { and international level. }\end{array}$ \\
\hline
\end{tabular}

On the basis of the data obtained from the indirect survey, four geological sites were chosen, namely, the Sungai Tekala and the Sungai Congkak waterfalls and the 
Semenyih and Sungai Serai Hot Springs (Figure 2).A direct survey was conducted using the geological heritage source field assessment form. Geological site heritage assessment was performed by geologists and final-year geology students. The assessment form was divided into three parts: 1). general information of a geosite, 2). information on heritage characterisation and 3). information on the management of a geosite. Parts 1 and 3 (Tables 1 and 3) focused on explaining the general data and the management of a geological site on the basis of literature reviews and field observation. Alphanumeric data from both parts encompassed the type of geosite, the name of geosite, the diversity code, the state, district and administrative division code, coordinates, land use status and accessibility and development proposals. The data in this alphanumeric form were stored in a database using a geographical information system to enable spatial analysis (for example, classification and selection) of a geological site heritage assessment to be conducted with ease (Reynard et al., 2007; Reynard et al., 2016).

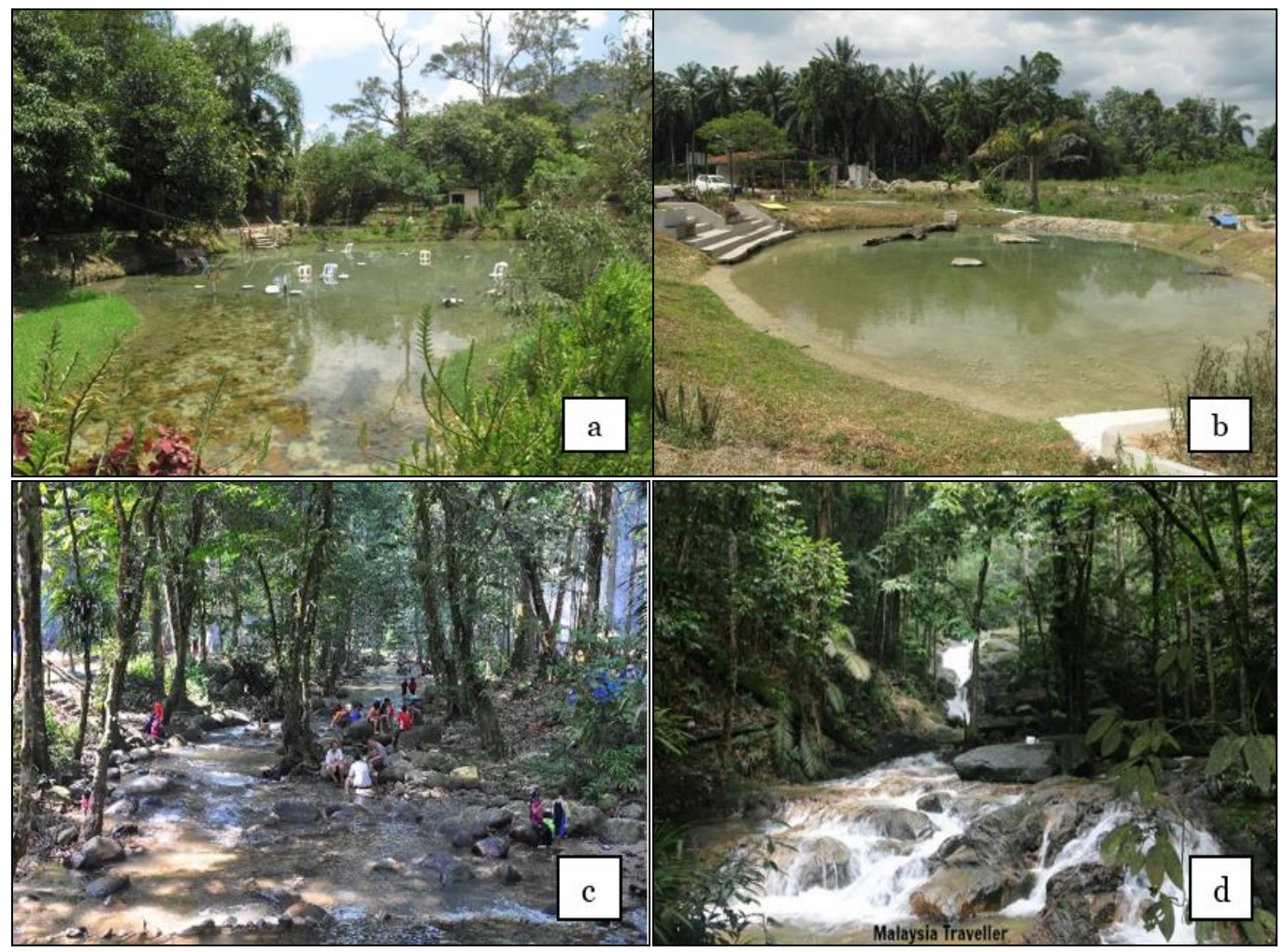

Figure 2 Image of four geological sites chosen for the study namely, the Sungai Serai Hot spring (a), Semenyih Hot Springs (b), Sungai Congkak (c) and Sungai Tekala (d) waterfalls

To conduct the heritage assessment of a geological site, the assessment component was consistently based on a set of scientific, aesthetic, recreational and cultural values (Komoo, 2000). With regard to Part 2, information about heritage characterisation was the criteria developed to conduct scientific, aesthetic, recreational and cultural assessment of a geological site (Table 2). The framework for the heritage assessment of a geological site was established based on the conservation geology approach, which incorporates criteria from various disciplines. Each value set was accorded a score between 1 and 5 (Rovere et al., 2010; Rovere et al., 2011). 
Table 2. Heritage characterisation information for scientific, aesthetic, recreational and cultural criteria (Data source: Armenski et al., 2012; Brilha, 2016; Dwyer \& Kim, 2003; Goffi, 2013; Komoo \& Othman 2001; Kane, 1976; Leopold 1969; Pereira et al., 2007; Vengesayi, 2003)

\begin{tabular}{|c|c|}
\hline \multicolumn{2}{|c|}{ Part 2: Heritage Characterisation Information } \\
\hline \multicolumn{2}{|c|}{ Scientific Assessment Criteria } \\
\hline $\begin{array}{l}\text { General Landscape } \\
\text { - } \quad \text { Mountains (peaks, ridges and plateau) } \\
\text { - } \text { Hill (peaks, ridges, plateau and rolling) } \\
\text { - } \text { Plain (alluvial, coastal) } \\
\text { - } \text { Island (individual, group) } \\
\text { single fall, double fall and almost vertical fall) } \\
\text { - Hot springs }\end{array}$ & $\begin{array}{l}\text { Geological Terrain } \\
\text { - Igneous (plutonic, volcanic and hypabyssal) } \\
\text { - } \text { Metamorphic (massive, foliated) } \\
\text { Sediment (clastic-massive, clastic-layered, } \\
\text { carbonate, evaporates and } \\
\text { unconsolidated) }\end{array}$ \\
\hline $\begin{array}{l}\text { Internal Process } \\
\text { - Lifting (plutonism, diapirism and isostatic } \\
\text { adjustment) } \\
\text { - Compression (tectonic plate boundary) } \\
\text { - Wrenching rifting (tectonic plate boundary) } \\
\text { - Volcanism (eruption, flow) }\end{array}$ & $\begin{array}{l}\text { External Process } \\
\text { - Weathering (physical, chemistry and biochemical) } \\
\text { - Erosion (glacier, water, wind, waves and biogenic) } \\
\text { - Deposition (slope, stream, lake, swamp, } \\
\text { shallow marine and deep marine) } \\
\text { - Mass movement (fall, slide and flow) } \\
\text { - Extra-terrestrial (crater) }\end{array}$ \\
\hline $\begin{array}{l}\text { Temporal Evolution } \\
\text { - Geological age (Precambrian, Mesozoic, } \\
\text { Tertiary and Quaternary) } \\
\text { - Maturity (old, mature and young) } \\
\text { - Types (static [fossil], active) }\end{array}$ & $\begin{array}{l}\text { Special Features } \\
\text { - Structure } \\
\text { - Water quality } \\
\text { - Temperature } \\
\text { - pH } \\
\text { - Chemical contents } \\
\text { - Landform size }\end{array}$ \\
\hline \multicolumn{2}{|c|}{ Aesthetic Assessment Criteria } \\
\hline $\begin{array}{l}\text { Viewpoint } \\
\text { - Different viewpoint } \\
\text { - Height (various levels) } \\
\text { - Distance in view } \\
\text { - Total viewpoints }\end{array}$ & $\begin{array}{l}\text { Main landform view } \\
\text { - Placement (no other landform) } \\
\text { - Clear (no obstruction) } \\
\text { - Other environmental features } \\
\text { (natural/saturated builds) }\end{array}$ \\
\hline $\begin{array}{l}\text { Panorama quality } \\
\text { - Environment (appeal to the ordinary) } \\
\text { - Appeal } \\
\text { - Uniqueness }\end{array}$ & $\begin{array}{l}\text { Presence of water resources and vegetation } \\
\text { - Water colour } \\
\text { - Water cleanliness } \\
\text { - Water volume } \\
\text { - Forest } \\
\text { - Bush } \\
\text { - Water movement sound } \\
\end{array}$ \\
\hline $\begin{array}{l}\text { Combinations of objects and colour } \\
\text { variations } \\
\text { - Colour contra } \\
\text { - Natural colour } \\
\text { - Natural appearance } \\
\text { - Manmade appearance } \\
\end{array}$ & $\begin{array}{l}\text { Human influence } \\
\text { - Erosion } \\
\text { - Urbanisation rate } \\
\text { - Industrial area } \\
\text { - Draining place } \\
\text { - Presence of garbage } \\
\end{array}$ \\
\hline $\begin{array}{l}\text { Proximity to the landforms } \\
\text { - Feel/touch the texture } \\
\text { - Warmth } \\
\text { - Coolness }\end{array}$ & $\begin{array}{l}\text { Composition and temporary factors } \\
\text { - Comfortable } \\
\text { - Presence of shadow } \\
\text { - Presence of cloud } \\
\text { - Presence of wind } \\
\text { - Presence of animal sounds } \\
\text { - Presence of manmade sounds } \\
\end{array}$ \\
\hline \multicolumn{2}{|c|}{ Recreational Assessment Criteria } \\
\hline Exposure & Accessibility \\
\hline
\end{tabular}




\begin{tabular}{|c|c|}
\hline $\begin{array}{l}\text { - Human activity (unrestricted recreation) } \\
\text { - Natural process (weathering and so on) } \\
\text { - Manmade disaster } \\
\text { - Natural disaster }\end{array}$ & $\begin{array}{l}\text { - Road network (high accessibility) } \\
\text { - Small street (not paved/tarred/trailed) } \\
\text { - Main street (paved/tarred) } \\
\text { - Transportation (bus, car and so on) }\end{array}$ \\
\hline $\begin{array}{l}\text { Public facilities } \\
\text { - Information counter } \\
\text { - Carpark } \\
\text { - Public toilet } \\
\text { - Restaurant } \\
\text { - Signboards } \\
\text { - Resthouse }\end{array}$ & $\begin{array}{l}\text { Safety aspects } \\
\text { - Near health centres } \\
\text { - Mobile health services } \\
\text { - Public safety ranger } \\
\text { - Warning signboards }\end{array}$ \\
\hline $\begin{array}{l}\text { Recreational appeal } \\
\text { - Trekking } \\
\text { - Climbing } \\
\text { - Camping } \\
\text { - Picnic } \\
\text { - Bathing/swimming } \\
\text { - Cycling } \\
\text { - Observing wildlife (birds and so on) }\end{array}$ & \\
\hline \multicolumn{2}{|c|}{ Cultural Assessment Criteria } \\
\hline $\begin{array}{l}\text { Importance of religion } \\
\text { - Religious myth } \\
\text { - Religious site } \\
\text { - Local tradition }\end{array}$ & $\begin{array}{l}\text { Importance of history } \\
\text { - Archaelogy site } \\
\text { - Prehistory } \\
\text { - Historical site } \\
\text { - Early settlement (Orang Asli Village, } \\
\text { traditional village) } \\
\text { - Tourism site } \\
\text { - Agriculture }\end{array}$ \\
\hline $\begin{array}{l}\text { Importance of art and literature } \\
\text { - Art } \\
\text { Carving (wood, stone and so on) } \\
\text { Poems } \\
\text { Folklore }\end{array}$ & \\
\hline
\end{tabular}

The explanation for each given score was based on the example recommended by researchers (Pereira et al., 2007; Reynard et al., 2007; Rovere et al., 2010; Rovere et al., 2011) and was adopted and modified within the assessment framework to be synchronised with the geological heritage source in Hulu Langat. The scientific value was an aspect that could be directly identified by geologists and geomorphologists (Table 4). On the other hand, the non-scientific values (namely, aesthetics, recreational and cultural) referred to various other disciplines from the geological field (Table 5). The conducted assessment was based on bibliographical data and simple criteria (Reynard et al., 2007) obtained from various non-scientific concepts. Although the main focus was the scientific value of a geological site, the non-scientific element was crucial in highlighting the relationship between the geological landscape (scientific) and the aesthetic, recreational and cultural aspects of the site itself.

Table 3. Information regarding geosite management (Data source: Komoo et al., 2004)

\begin{tabular}{|c|c|c|}
\hline \multicolumn{3}{|c|}{ Part 3: Geosite Management Information } \\
\hline $\begin{array}{l}\text { Land Use Status } \\
\text { Mark the current land use } \\
\text { status for local geological sites } \\
\text { (example: permanent forest } \\
\text { reserve and so on) }\end{array}$ & $\begin{array}{l}\text { Intuitive } \\
\text { Mark the accessibility level to } \\
\text { the geological site locality } \\
\text { (example: high, low and } \\
\text { moderate) }\end{array}$ & $\begin{array}{l}\text { Development Proposals } \\
\text { Mark the development } \\
\text { proposals for the identified } \\
\text { localities (example: reserve site } \\
\text { and so on) }\end{array}$ \\
\hline
\end{tabular}


Table 4. Criteria for evaluation of scientific values that are adopted and modified

(Data source: Rovere et al., 2010, 2011)

\begin{tabular}{|c|c|c|c|c|c|}
\hline & 1 & 2 & 3 & 4 & 5 \\
\hline Integrity (INT) & $\begin{array}{c}\text { Low } \\
\text { conservation } \\
\text { effects due to } \\
\text { human activities } \\
\text { and natural } \\
\text { processes }\end{array}$ & $\begin{array}{c}\text { Low } \\
\text { conservation } \\
\text { due to human } \\
\text { activities }\end{array}$ & $\begin{array}{c}\text { Destruction of } \\
\text { the earth's } \\
\text { surface occurs, } \\
\text { but the landscape } \\
\text { integrity is } \\
\text { preserved }\end{array}$ & $\begin{array}{c}\text { Conservation is } \\
\text { good due to } \\
\text { human } \\
\text { intervention }\end{array}$ & $\begin{array}{c}\text { Good } \\
\text { conservation due } \\
\text { to natural } \\
\text { conditions }\end{array}$ \\
\hline $\begin{array}{l}\text { Representative } \\
\text { ness (REP) }\end{array}$ & $\begin{array}{l}\text { Moderate in } \\
\text { explaining the } \\
\text { process or } \\
\text { formation of } \\
\text { the earth }\end{array}$ & $\begin{array}{l}\text { Good in } \\
\text { explaining the } \\
\text { process or } \\
\text { formation of } \\
\text { the earth }\end{array}$ & $\begin{array}{l}\text { Reference site } \\
\text { (scientific } \\
\text { reading) to } \\
\text { describe the } \\
\text { process or } \\
\text { formation of } \\
\text { the earth }\end{array}$ & \begin{tabular}{|c|} 
Site is used as a \\
reference to \\
describe the \\
process or \\
formation of the \\
earth \\
\end{tabular} & $\begin{array}{l}\text { Outstanding and } \\
\text { extraordinary site } \\
\text { that is used to } \\
\text { describe the } \\
\text { process or } \\
\text { formation of the } \\
\text { earth carefully }\end{array}$ \\
\hline $\begin{array}{l}\text { Rareness } \\
\text { (RAR) }\end{array}$ & $\begin{array}{l}\text { Rarely found } \\
\text { on a local scale }\end{array}$ & $\begin{array}{l}\text { Rarely found } \\
\text { on a state scale }\end{array}$ & $\begin{array}{l}\text { Rarely found } \\
\text { on a country - } \\
\text { level scale }\end{array}$ & $\begin{array}{l}\text { Rarely found on } \\
\text { a regional scale } \\
\text { (example: scaleof } \\
\text { Southeast Asia) }\end{array}$ & $\begin{array}{c}\text { Rarely found on } \\
\text { an international } \\
\text { or global scale }\end{array}$ \\
\hline $\begin{array}{l}\text { cientific } \\
\text { ignificance (ScS) }\end{array}$ & $\begin{array}{c}\text { Important on a } \\
\text { local scale }\end{array}$ & $\begin{array}{l}\text { Important on a } \\
\text { state scale }\end{array}$ & $\begin{array}{l}\text { Important on a } \\
\text { country-level scale }\end{array}$ & $\begin{array}{l}\text { Important on a } \\
\text { regional scale }\end{array}$ & $\begin{array}{l}\text { Important on a } \\
\text { global scale }\end{array}$ \\
\hline
\end{tabular}

Table 5. Criteria for evaluation of non-scientific values that are adopted and modified

(Data source: Reynard et al., 2007)

\begin{tabular}{|l|c|c|c|c|c|}
\hline & 1 & 2 & 3 & 4 & 5 \\
\hline $\begin{array}{l}\text { Aesthetic } \\
\text { (AES) }\end{array}$ & $\begin{array}{c}\text { Moderate appeal } \\
\text { in explaining the } \\
\text { aesthetic aspects } \\
\text { of human } \\
\text { intervention }\end{array}$ & $\begin{array}{c}\text { Good appeal in } \\
\text { explaining } \\
\text { aesthetic aspects } \\
\text { due to natural } \\
\text { processes }\end{array}$ & $\begin{array}{c}\text { High appeal in } \\
\text { explaining the } \\
\text { aesthetic } \\
\text { aspects in } \\
\text { relation to } \\
\text { natural and } \\
\text { human } \\
\text { processes }\end{array}$ & $\begin{array}{c}\text { Aesthetic site is } \\
\text { important in } \\
\text { relation to the } \\
\text { process and } \\
\text { formation of } \\
\text { the earth }\end{array}$ & $\begin{array}{c}\text { Extraordinary } \\
\text { and superior } \\
\text { aesthetic site that } \\
\text { shows the } \\
\text { intrinsic value in } \\
\text { the process and } \\
\text { the formation of } \\
\text { the earth }\end{array}$ \\
\hline $\begin{array}{l}\text { Recreation } \\
\text { (REC) }\end{array}$ & $\begin{array}{c}\text { Moderate in } \\
\text { explaining } \\
\text { recreational } \\
\text { aspects }\end{array}$ & $\begin{array}{c}\text { Good in } \\
\text { explaining } \\
\text { recreational } \\
\text { aspects in } \\
\text { connection with } \\
\text { natural processes }\end{array}$ & $\begin{array}{c}\text { High in } \\
\text { explaining the } \\
\text { recreation } \\
\text { aspect as it } \\
\text { relates to the } \\
\text { natural and } \\
\text { human } \\
\text { processes }\end{array}$ & $\begin{array}{c}\text { Recreational } \\
\text { sites are } \\
\text { important in } \\
\text { relation to } \\
\text { aspects of the } \\
\text { process and the } \\
\text { formation of } \\
\text { the earth }\end{array}$ & $\begin{array}{c}\text { Exceptional } \\
\text { recreational sites } \\
\text { that relate to } \\
\text { aspects of the } \\
\text { process and the } \\
\text { formation of } \\
\text { the earth }\end{array}$ \\
\hline $\begin{array}{l}\text { Cultural } \\
\text { (CUL) }\end{array}$ & $\begin{array}{c}\text { Moderate in } \\
\text { explaining a } \\
\text { cultural trait }\end{array}$ & $\begin{array}{c}\text { Good in } \\
\text { explaining cultural } \\
\text { characteristics but } \\
\text { not in relation to } \\
\text { the shape of } \\
\text { the earth }\end{array}$ & $\begin{array}{c}\text { Sites that have } \\
\text { insignificant } \\
\text { cultural } \\
\text { features in } \\
\text { relation to the } \\
\text { earth's terrain }\end{array}$ & $\begin{array}{c}\text { Sites that have } \\
\text { tangible cultural } \\
\text { features in } \\
\text { relation to the } \\
\text { earth's terrain }\end{array}$ & $\begin{array}{c}\text { Anthropic } \\
\text { shaped terrain } \\
\text { with high } \\
\text { cultural } \\
\text { relevance }\end{array}$ \\
\hline
\end{tabular}

RESULTS AND ANALYSIS OF ASSESSMENT

The assessment conducted on the four selected sites to determine the type of geological site in Hulu Langat produced scores with different values. The scientific assessment (Figure 3) score for the entire geological site was moderate compared with the recreational and aesthetic value scores, which were much higher than the cultural value 
score. Although the scientific assessment score was moderate as a result of certain scientific significances (such as geological terrain, internal/external processes and special features), its rarity was common on a local scale. Nevertheless, the integrity of a geological site was still preserved, especially as a waterfall locality, because it is situated in Hulu Langat's PFR area, away from the settlement's saturated area. The recreational (Figure 5) and aesthetic (Figure 4) values recorded the highest assessment score, especially at the Tekala River and the Congkak River waterfall areas. These results were attributed to the good development and maintainance of the waterfall areas, which were designated as green recreational areas by the State Forestry Department in 1978 and 1992 and by Selangor Tourism in 2005, thereby ensuring that the aesthetic view of the rainforest was sustained. The high accessibility of the waterfall locality, which is situated close to the Sungai Lalang and Hulu Langat main road, was one of the factors for the high recreational and aesthetic value scores. However, the recreational and aesthetic assessment scores for the Sungai Serai and Semenyih Hot Springs locality were lower than the scores for the waterfall areas. Private land ownership and the location of the hot springs, which is in the vicinity of a settlement's saturated area and agricultural region, resulted in the lower scores for these two values.The cultural assessment (Figure 6) aspect projected the lowest score (below 1.5) for the overall geological site assessed. The low cultural value was caused by insufficient information and written evidence of history, religion, art and literature aspects that could be related to the locality of the geological site. The score obtained from the assessment was applied to determine the type of geological site (geofeatures, geosite and geotop) for geotourism and conservation (Table 7). The end result of the assessment on the four identified sites revealed that the locality of a geological site was at scales 1 and 2, which were only for geofeatures. The numerical assessment results or scores for the geological heritage site in this research are listed in Table 6.

Table 6. Scores for geological site heritage assessment according to diversity by using the geological conservation approach in Hulu Langat District, Selangor

\begin{tabular}{|c|c|c|c|c|c|c|c|}
\hline Code & $\begin{array}{c}\text { Name of } \\
\text { Geological Site }\end{array}$ & $\begin{array}{l}\text { Latitude/ } \\
\text { Longitude }\end{array}$ & \begin{tabular}{|c|} 
Scientific \\
Score \\
\end{tabular} & $\begin{array}{c}\text { Aesthetic } \\
\text { Score }\end{array}$ & $\begin{array}{c}\text { Recreational } \\
\text { Score }\end{array}$ & $\begin{array}{l}\text { Cultural } \\
\text { Score } \\
\end{array}$ & $\begin{array}{l}\text { Total Score [SCI+ } \\
\text { AES+REC+CUL/4] }\end{array}$ \\
\hline $\begin{array}{c}\text { BT/ST/ } \\
\text { RB-10/A1 }\end{array}$ & $\begin{array}{c}\text { Sungai } \\
\text { Tekala Waterfall }\end{array}$ & $\begin{array}{c}3^{\circ} 3 \text { '30.02"N } \\
101^{\circ} 52^{\prime} 19.00^{\prime \prime} \mathrm{E}\end{array}$ & 2.13 & 2.67 & 2.53 & 1.40 & 2.18 \\
\hline $\begin{array}{c}\text { BT/RB- } \\
\text { 10/A7 }\end{array}$ & $\begin{array}{c}\text { Sungai Congkak } \\
\text { Waterfall }\end{array}$ & $\begin{array}{c}3^{\circ} 12^{\prime} 32.18^{\prime \prime} \mathrm{N} \\
101^{\circ} 50^{\prime} 36.67^{\prime} \mathrm{E}\end{array}$ & 2.15 & 2.80 & 2.99 & 1.32 & 2.32 \\
\hline $\begin{array}{c}\text { ST/RB- } \\
\text { 10/H3 }\end{array}$ & $\begin{array}{c}\text { Sungai Serai } \\
\text { Hot Springs }\end{array}$ & $\begin{array}{c}3^{\circ} 5^{\prime} 26.70^{\prime \prime} \mathrm{N} \\
101^{\circ} 477^{\prime} 40.62^{\prime \prime} \mathrm{E}\end{array}$ & 1.67 & 1.76 & 2.08 & 1.07 & 1.65 \\
\hline $\begin{array}{l}\text { ST/RB- } \\
\text { 10/H4 }\end{array}$ & $\begin{array}{l}\text { Semenyih Hot } \\
\text { Springs }\end{array}$ & $\begin{array}{c}3^{\circ} 22^{\prime} 3237^{\prime} \mathrm{N} \\
101^{\circ} 52^{\prime} 20.47^{\prime} \mathrm{E}\end{array}$ & 1.74 & 1.75 & 1.91 & 1.14 & 1.64 \\
\hline
\end{tabular}

Table 7. Geological site scales based on the criteria of the heritage assessment

\begin{tabular}{|c|c|c|c|c|c|}
\hline Evaluation Criteria & \multicolumn{5}{|c|}{ Geological Site Scales } \\
\hline \multirow{5}{*}{$\begin{array}{c}\text { Scientific (SCI) } \\
\text { Aesthetics (AES) } \\
\text { Recreation (REC) } \\
\text { Cultural (CUL) } \\
\text { [(SCI+AES+ } \\
\text { REC+CUL)/4] }\end{array}$} & 1 & 2 & 3 & 4 & 5 \\
\hline & \multicolumn{2}{|c|}{ Geofeature } & \multicolumn{2}{|c|}{ Geosite } & Geotope \\
\hline & Low & Average & \multicolumn{2}{|c|}{ High } & Very High \\
\hline & Very common & Common & Uncommon & Rare & Outstanding Rare \\
\hline & $\begin{array}{l}\text { Contains useful } \\
\text { scientific record } \\
\text { that enhances } \\
\text { knowledge and is } \\
\text { suitable for } \\
\text { research } \\
\text { purposes }\end{array}$ & $\begin{array}{c}\text { Contains } \\
\text { important } \\
\text { scientific record } \\
\text { and suitable for } \\
\text { education and } \\
\text { research } \\
\text { purposes }\end{array}$ & \multicolumn{2}{|c|}{$\begin{array}{l}\text { Rare. In terms of scientific } \\
\text { record, special geological or } \\
\text { landform features, } \\
\text { significant occurrence or } \\
\text { distribution, special } \\
\text { ecological function or a } \\
\text { combination of any of these. }\end{array}$} & $\begin{array}{l}\text { Unique. In } \\
\text { terms of } \\
\text { scientific } \\
\text { record and } \\
\text { special } \\
\text { geological } \\
\text { features }\end{array}$ \\
\hline
\end{tabular}




\begin{tabular}{|c|c|c|c|c|c|}
\hline \multicolumn{6}{|c|}{ Scientific Value } \\
\hline \multicolumn{2}{|c|}{ Sungai Serai Hot Springs } & $x+\frac{1}{2}$ & 1.67 & & \\
\hline \multicolumn{2}{|c|}{ Semenyih Hot Springs } & $a_{n}$ & 1.74 & & \\
\hline \multicolumn{2}{|c|}{ Sungai Congkak Waterfall } & & 2.15 & & \\
\hline \multicolumn{2}{|c|}{ SungaiTekala Waterfall } & & \multicolumn{2}{|c|}{2.13} & \\
\hline & & 1 & 2 & 3 & 4 \\
\hline & \multicolumn{2}{|c|}{$\begin{array}{l}\text { SungaiTekala } \\
\text { Waterfall }\end{array}$} & $\begin{array}{c}\text { Sungai } \\
\text { Congkak } \\
\text { Waterfall }\end{array}$ & $\begin{array}{l}\text { Semenyih Hot } \\
\text { Springs }\end{array}$ & $\begin{array}{l}\text { Sungai Serai } \\
\text { Hot Springs }\end{array}$ \\
\hline E Scientific Value & \multicolumn{2}{|c|}{2.13} & 2.15 & 1.74 & 1.67 \\
\hline
\end{tabular}

Figure 3. Scientific assessment value between four selected geological sites

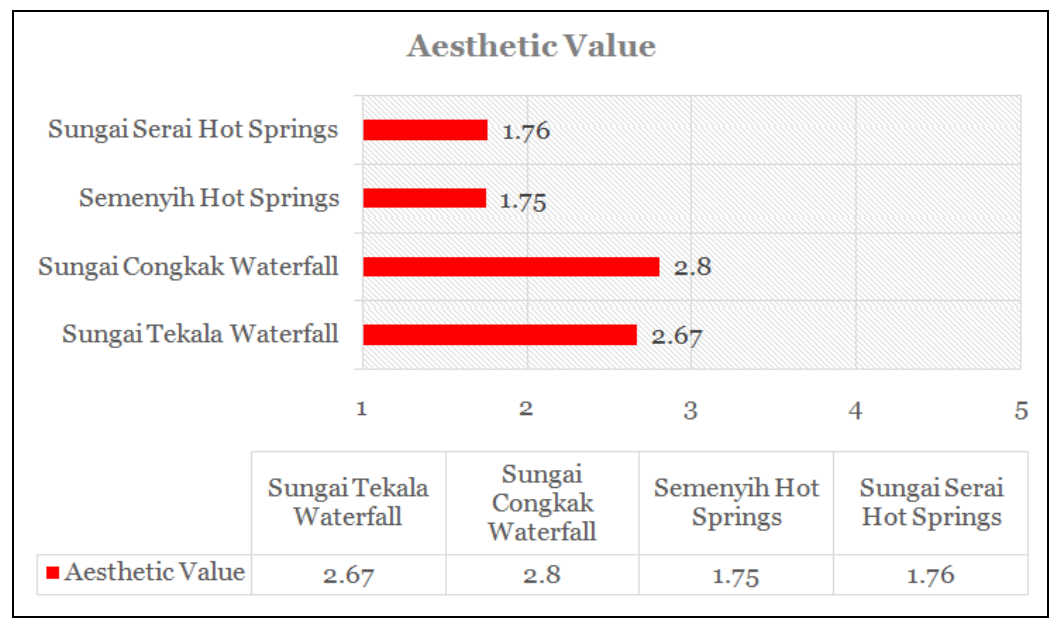

Figure 4. Aesthetic assessment value between four selected geological sites

\begin{tabular}{|c|c|c|c|c|c|}
\hline & & & ultural Valu & & \\
\hline SungaiSerai Hot & Springs & 1.07 & & & \\
\hline Semenyih Hot & Springs & 1.1 & & & \\
\hline Sungai Congkak & Taterfall & 1 & 1.32 & & \\
\hline Sungai Tekala $V$ & Taterfall & ent & 1.4 & & \\
\hline & & & 2 & 3 & 4 \\
\hline & $\begin{array}{l}\text { SungaiT } \\
\text { Waterf }\end{array}$ & & $\begin{array}{c}\text { Sungai Congkak } \\
\text { Waterfall }\end{array}$ & $\begin{array}{l}\text { Semenyih Hot } \\
\text { Springs }\end{array}$ & $\begin{array}{l}\text { Sungai Serai } \\
\text { HotSprings }\end{array}$ \\
\hline Cultural Value & 1.4 & & 1.32 & 1.14 & 1.07 \\
\hline
\end{tabular}

Figure 5. Recreation assessment value between four selected geological sites

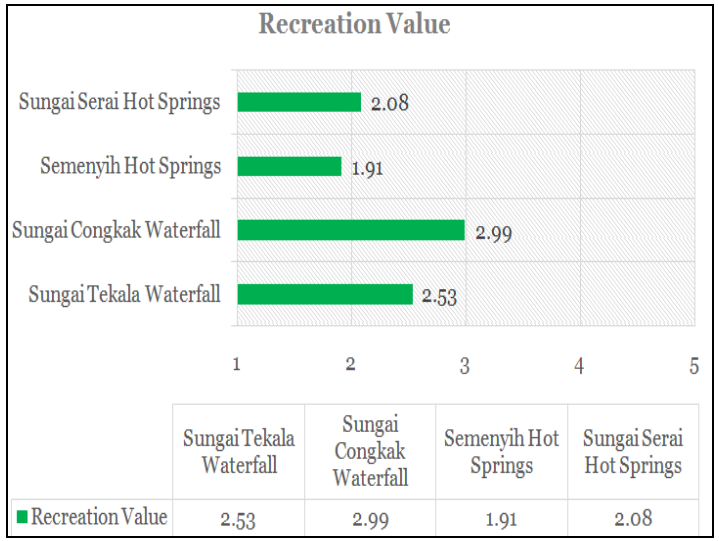

Figure 6. Cultural assessment value between four selected geological sites 


\section{CONCLUSION}

The main focus of this research paper was to determine the method that is used to assess the geological heritage site in Hulu Langat for the purpose of geotourism or conservation. The development of a marking or scoring system based on the quantitative measurement of scientific, aesthetic, recreational and cultural values was used to test the validity of the heritage value by using the conservation geology approach. This approach was the result of the combination of the geological landscape concept with various other disciplines (such as biology, history and economy). The results of the assessment on the locality of the four sites chosen for this purpose show that these sites are suitable geofeature sites because each site possesses a scientific record that could increase public awareness and plays an important role in enhancing education and research portfolios. The high recreational and aesthetic values also increased their suitability for use as a geotourism site in addition to being conserved because of the importance of their ecological system. The other identified localities around the Hulu Langat area with waterfalls, hot springs, hills, mountains and dams are also major factors in determining the significance and the type of geological site to be allotted as sites for tourism, recreational or conservation purposes. The assessment of each of these sites was merely an approach in determining the importance of a particular geological site. Continued effort in conserving areas with valuable natural resources has to include all layers of society to allow the current and future generations to benefit from the fruitful results.

\section{Acknowledgments}

This paper is a research on the characterisation and the assessment of the various geosites around the Hulu Langat area for the purpose of geotourism under the Fundamental Research Grant Scheme (FRGS/1/2014/STWNo6/UKM/O2/4) under the purview of Dr. Tanot Unjah, research fellow at LESTARI, UKM and also supported by the research university grant (GUP-2017-083) lead by Dr. Norbert Simon. Warm appreciation and gratitude are extended to the leader of the project and fellow researchers for the discussion sessions and their support in the form of various ideas that they shared for the purpose of completing this research paper.

\section{REFERENCES}

Armenski, T., Gomezelj, D. O., Djurdjev, B., Curčić, N., \& Dragin, A. (2012). Tourism Destination Competitiveness- Between Two Flags. Ekonomska Istrazivanja-Economic Research, 25(2), 485-502.

Brilha, J. (2016). Inventory and Quantitative Assessment of Geosites and Geodiversity Sites: a Review. Geoheritage, 8(2), 119-134.

Doyle, P., Easterbrook, G., Reid, E., Skipsey, E., \& Wilson, C. (1994). Earth Heritage Conservation. (C. Wilson, Ed.). London: Geological Society and Open University.

Dwyer, L., \& Kim, C. (2003). Destination Competitiveness: Determinants and Indicators. Current Issues in Tourism, 6(5), 369-414.

Goffi, G. (2013). A Model of Tourism Destination Competitiveness: The case of the Italian Destinations of Excellence. Turismo y Sociedad, 14(0), 121-147.

Hakim, L. \& Seomarno , M. (2017). Biodiversity conservation , community development and geotourism development in Bromo-Tengger-Semeru-Arjuno Biosphere Reserve, East Java. Geojournal of Tourism and Geosite. 2(20) p. 230-230

Hussein, M. K., Abdullah, S. A., Siwar, C., \& Mohamad Ismail. S. (2013). Analysis on the development of recreational forest landscapes in selangor, Malaysia. Geografia ; Malaysian Journal of Society and Space, 3(3), 1-11.

Komoo, I. (2000). Conseration Geology: A Multidisciplinary Approach in Utilization of Earth Resources without Destruction. In Ibrahim Komoo \& H.D Tjia (Eds.), Warisan Geologi Malaysia: Resource development for conservation and nature tourism (p. 3-11). Bangi: Institut Alam Sekitar dan Pembangunan (LESTARI), Universiti Kebangsaan Malaysia.

Komoo, I. (2003). Conservation Geology - Protecting hidden treasure of Malaysia. (Ibrahim Komoo, Ed.)ASM Inaugural Lectures. Bangi: Institute for Environment and Development (LESTARI) Universiti Kebangsaan Malaysia, Bangi Selangor. 
Komoo, I. \& Md Desa. K. (1997). Conservation Geology: a case for the ecotourism industry of Malaysia. In Geological Heritage of Malaysia: Geological Heritage of Malaysia: Conservation geology for ecotourism In Ibrahim Komoo, Mohd Shafeea Leman, Kadderi Md Desa \& Ibrahim Abdullah (Eds.), Geological Heritage of Malaysia: Conservation geology for ecotourism (p. 85-96). Bangi: Institute for Environment and Development (LESTARI), Universiti Kebangsaan Malaysia.

Komoo, I., Lim C. S., Unjah, T., Sarman, M. \& Ismail S. (2004). Geological heritage of malaysian database for conservation and sustainable use. In Mohd Shafeea Leman \& Ibrahim Komoo (Eds.), Geological Heritage of Malaysia: Theoritical framework and assessment of geoheritage (p. 3-13). Bangi: Institute for Environment and Development (LESTARI), Universiti Kebangsaan Malaysia.

Komoo, I., \& Othman. M. (2001). Geological Landscape: definition and characterisation for conservation. In Ibrahim Komoo, H. D. Tjia, \& Mohd Shafeea Leman (Eds.), Geological Heritage of Malaysia: Geoheritage mapping and geosite characterization (p. 481-489). Bangi: Institute for Environment and Development (LESTARI), Universiti Kebangsaan Malaysia.

Komoo, I., Abdul Razak, Y., Suratman, S., Leman, M. S., Mohamed, K. R. \& Jasin. B. (2001). Geological heritage mapping programme in malaysia. In Ibrahim Komoo, H. D. Tjia, \& Mohd Shafeea Leman (Eds.), Geological Heritage of Malaysia: Geoheritage mapping and geosite characterization (p. 3-15). Bangi: Institute for Environment and Development (LESTARI), Universiti Kebangsaan Malaysia.

Kane, P. S. (1976). Evaluating landscape attractiveness : a review of problems and methods and a technique developed for the National Trust of South Australia (National T). Adelaide : National Trust of South Australia, 1976.

Leopold, L. B. (1969). Quantitative comparison of some aesthetic factors among rivers. U. S. Geological Survey Circular, 12.

Leman, M. S., Komoo, I., Mohamad Ismail, S., \& Rahman, A. A. (2007). Geological heritage conservation within Malaysian geoforest parks and recreational forests. In Mohd Shafeea Leman, Che Aziz Ali, \& Ibrahim Komoo (Eds.), Geological Heritage of Malaysia: Geoheritage resource conservation and environmental protection (p. 443-456). Bangi: Institute for Environment and Development (LESTARI), Universiti Kebangsaan Malaysia.

Norhayati, M. R., \& Juhari, M. A. (2000). Mapping of geomorphic upper langat basin with aerial photographs assistance. Geological Society of Malaysia Annual Geological Conference, 411-414.

Pereira, P., Pereira, D., \& Caetanno Alves, M. I. (2007). Geomorphosite assesment in Montesinho Natural Park (Portugal). Geographica Helvetica, 62(3), 159-168.

Reynard, E., Fontana, G., Kozlik, L., \& Scapozza, C. (2007). A method for assessing "scientific" and "additional values" of geomorphosites. Geographica Helvetica, 62(3), 148-158.

Reynard, E., Perret, A., Bussard, J., Grangier, L., \& Martin, S. (2016). Integrated Approach for the Inventory and Management of Geomorphological Heritage at the Regional Scale. Geoheritage, 8(1), 43-60.

Rovere, A., Vacchi, M., Parravicini, V., Bianchi, C. N., Zouros, N., \& Firpo, M. (2011). Bringing geoheritage underwater: Definitions, methods, and application in two Mediterranean marine areas. Environmental Earth Sciences, 64(1), 133-142.

Rovere, A., Vacchi, M., Parravicini, V., Morri, C., Bianchi, C. N., \& Firpo, M. (2010). Bringing geoheritage underwater: methodological approaches to evaluation and mapping. Mapping Geoheritage, $65-80$.

Sarman, M., Badang, D., Komoo, I., \& Md Desa. K. (1999). Framework of conservation and tourism geology for development for geoscience information. In Ibrahim Komoo \& Mohd Shafeea Leman (Eds.), Geological Heritage of Malaysia: Conservation geology for geotope development (pp. 99-116). Bangi: Institute for Environment and Development (LESTARI), Universiti Kebangsaan Malaysia.

Sharples, C. (1993). A Methodology for the Identification of Significant Landforms and Geological Sites for Geoconservation Purposes.

Sharples, C. (2002). Concepts and Principles Of Geoconservation. Tasmanian Geoconservation Database. Tasmania. Australia

Unjah. T. (2003). Characterization and assessment of geological heritage resources, state of Kelantan (Unpublished master's thesis). Institute or Environment and Development (LESTARI), Universiti Kebangsaan Malaysia, Bangi, Selangor.

Vengesayi, S. (2003). a Conceptual Model of Tourism Destination Competitiveness and Attractiveness. Conceptual Papers / Marketing Theory Track, (December), 637-647.

Zabidi, H., Abdullah, I. \& Abdul Rahman, Z. (2001). Preliminary mapping of geological heritage resources in Selangor and Federal Teritory Kuala Lumpur. In Ibrahim Komoo, H. D. Tjia, \& M. S. Leman (Eds.), Geological Heritage of Malaysia: Geoheritage mapping and geosite characterization (pp. 17-26). Bangi: Institute for Environment and Development (LESTARI), Universiti Kebangsaan Malaysia.

Submitted:

22.06.2018
Revised:

23.11.2018
Accepted and published online 26.11.2018 